\title{
GRAVITY SURVEY OF THE PANTANAL WETLAND: DATA ACQUISITION AND PROCESSING
}

\author{
Shozo Shiraiwa ${ }^{1} \&$ Naomi Ussami ${ }^{2}$
}

Received November 15, 2001 / Accepted July 18, 2002

\begin{abstract}
A gravity survey was conducted between 1988 and 1993, mostly during the dry season (july to october) in the Pantanal Wetland and surrounding highlands, aiming to obtain a first regional gravity coverage. The Pantanal Wetland is an important geomorphological unit extending from $-54^{\circ}$ to $-59 .^{\circ}$, east-west, and from $14^{\circ}$ to $23^{\circ}$, north-south, in SW Brazil. The topography ranges from $80 \mathrm{~m}$ to $200 \mathrm{~m}$ above sea level within the plain. A total of 3,662 gravity stations were collected. Because of the difficulty in accessing the flood plain, apart from conventional ground survey, fluvial and air routes were used in the field data acquisition. The data acquisition procedure is described in detail and a discussion on the final gravity anomaly accuracy is presented. From the total number of stations, 7 stations belong to the Fundamental Brazilian Gravity Network, 1,886 gravity stations were obtained on bench marks, 1,505 stations were set up together with barometric levelling or the altitude was estimated from topographic maps in places with smooth topography (horizontal gradient $<0.5 \mathrm{~m} / \mathrm{km}$ ), 237 stations were collected along the main rivers and 33 stations using aircraft.
\end{abstract}

Key Words: Gravity survey; Pantanal wetland; Regional bouguer anomalies.

LEVANTAMENTO GRAVIMÉTRICO NO PANTANAL MATOGROSSENSE: AQUISIÇÃO E PROCESSAMENTO DE DADOS - Um levantamento gravimétrico foi conduzido entre 1988 e 1993, principalmente durante o período de sêca (julho a outubro) no interior da planície do Pantanal Matogrossense e planaltos vizinhos, com o objetivo de obter uma primeira cobertura gravimétrica regional. O Pantanal Matogrossense é uma importante unidade geomorfológica que se estende entre $54^{\circ}$ e $59^{\circ} \mathrm{W}$, leste-oeste, e entre $14^{\circ}$ e $23^{\circ} \mathrm{S}$, norte-sul, no sudoeste do Brasil. A topografia varia entre $80 \mathrm{~m}$ e $200 \mathrm{~m}$ acima do nível do mar no interior da planície. Um total de 3.662 estações gravimétricas foram coletadas. Devido à dificuldade de acessar a planície de inundação, além do levantamento gravimétrico terrestre convencional, acessos fluvial e aéreo também foram utilizados na aquisição de dados de campo. Os procedimentos de aquisição de dados são descritos em detalhe e uma discussão da precisão sobre a anomalia gravimétrica final é apresentada. Do total das estações gravimétricas, 7 estações pertencem à Rede Gravimétrica Fundamental Brasileira, 1.886 estações foram obtidas sobre referências de nível, 1.234 estações foram medidas em conjunto com um levantamento barométrico ou a altitude foi estimada a partir de cartas topográficas em locais de topografia suave (gradiente horizontal $<0,5 \mathrm{~m} / \mathrm{km}$ ), 237 estações foram coletadas nas margens dos principais rios $e$ 33 estações utilizando uma aeronave.

Palavras-chave: Levantamento gravimétrico; Pantanal matogrossense; Anomalias Bouguer.

\author{
${ }^{1}$ Depto. de Física \\ Universidade Federal do Mato Grosso \\ Instituto de Ciências Exatas e da Terra \\ Av. Fernando Correia da Costa s/no. \\ Cuiabá, MT, 78060-900 \\ shozo@cpd.ufmt.br \\ ${ }^{2}$ Depto. de Geofísica \\ Universidade de São Paulo \\ Instituto de Astronomia, Geofísica e Ciências Atmosféricas \\ Rua do Matão 1226 \\ São Paulo, SP - 05508-900 \\ naomi@iag.usp.br
}




\section{INTRODUCTION}

Regional gravity surveys are fundamental data in applications ranging from natural resources exploration to geodesy and geodynamics. In Brazil, several institutions are responsible for conducting systematic and long term gravity data collection (see Sá et al., 1993; Molina et al., 2000 for references). However, a desired high-resolution $(<5 \mathrm{~km})$ coverage for most of Brazil is far to be completed. The average resolution of the regional gravity maps in Brazil is not better than $10 \mathrm{~km}$, with large areas in the western and northern parts of the country completely devoid of gravity data. Since the initial stages of regional gravity data collection, IAG-USP adopted the procedure of setting up the gravity stations on bench marks, named as RN by the Instituto Brasileiro de Geografia e Estatística IBGE and Diretoria do Serviço Geográfico do Exército - DSG, along the main roads. Altitudes of bench mark are obtained using geometric leveling with centimeter accuracy and spaced every 2-3 km. Most of the available bench marks in Brazil are presently gravity stations and this routine of gravity data acquisition is still used whenever a new line of bench marks is established.

The prospect to improve the regional gravity coverage in Brazil is very promissing with the use of differential GPS systems (DGPS) for altitude determination. However, the convertion from normal to orthometric altitude depends on having a highresolution local geoid model, which in its turn depends on gravity data. Therefore, to make full use of the GPS technology, one must start from basic regional gravity information.

In the present paper we describe the gravity data acquisition in the Pantanal Wetland and surrounding highlands which resulted in a 5' x5' Bouguer anomaly map. The regional and residual maps are also shown and qualitatively discussed.

The regional Bouguer gravity map of the Pantanal Wetland has already been used in tectonic studies (Shiraiwa, 1994; Ussami et al., 1999) and in the geoid map of Brazil (Molina \& Ussami, 1999) to study thermo-mechanical properties of the South American lithosphere.

\section{GRAVITY SURVEY}

The present gravity data distribution in the Pantanal Wetland and surrounding highlands is shown in Fig. 1.

\section{Fundamental Gravity Network}

The gravity densification survey in the Pantanal Wetland used 7 gravity reference stations of the RGFB (Rede Gravimétrica Fundamental Brasileira, ON, 1987) which is referred to the IGSN71 (Morelli et al., 1971). The stations and their gravity values are listed in Table 1 and the stations are shown in Fig. 1 as full squares.

\section{Second Order Gravity Network}

Due to the extent of the region to be surveyed and the difficult condition of vehicle dislocation within the Pantanal Wetland a second order gravity network was initially established to tie the gravimeter measurements to a gravity network within the maximum time interval of 48 hours in order to minimize instrumental drift effect.

For this purpose, three Lacoste \& Romberg Gtype model gravimeters were used: the G-454 from Instituto de Astronomia, Geofísica e Ciências

\begin{tabular}{|c|c|}
\hline Locality & g(mGal) \\
\hline Cuiabá "C" & $978,347.35$ \\
\hline Rondonópolis "B" & $978,359.90$ \\
\hline Campo Grande "B" & $978,495.11$ \\
\hline Porto Esperidião "B" & $978,386.01$ \\
\hline São Gabriel d"Oeste "B" & $978,407.28$ \\
\hline Cáceres "C" & $978,383.07$ \\
\hline Coxirn "B" & $978,486.03$ \\
\hline
\end{tabular}

Table 1 - Fundamental Brazilian Gravity Network (ON, 1987) used in the Pantanal gravity densification survey.

Tabela 1 - Rede Gravimétrica Brasileira Fundamental (ON, 1987) utilizada no trabalho de densificação gravimétrica no Pantanal Matogrossense. 


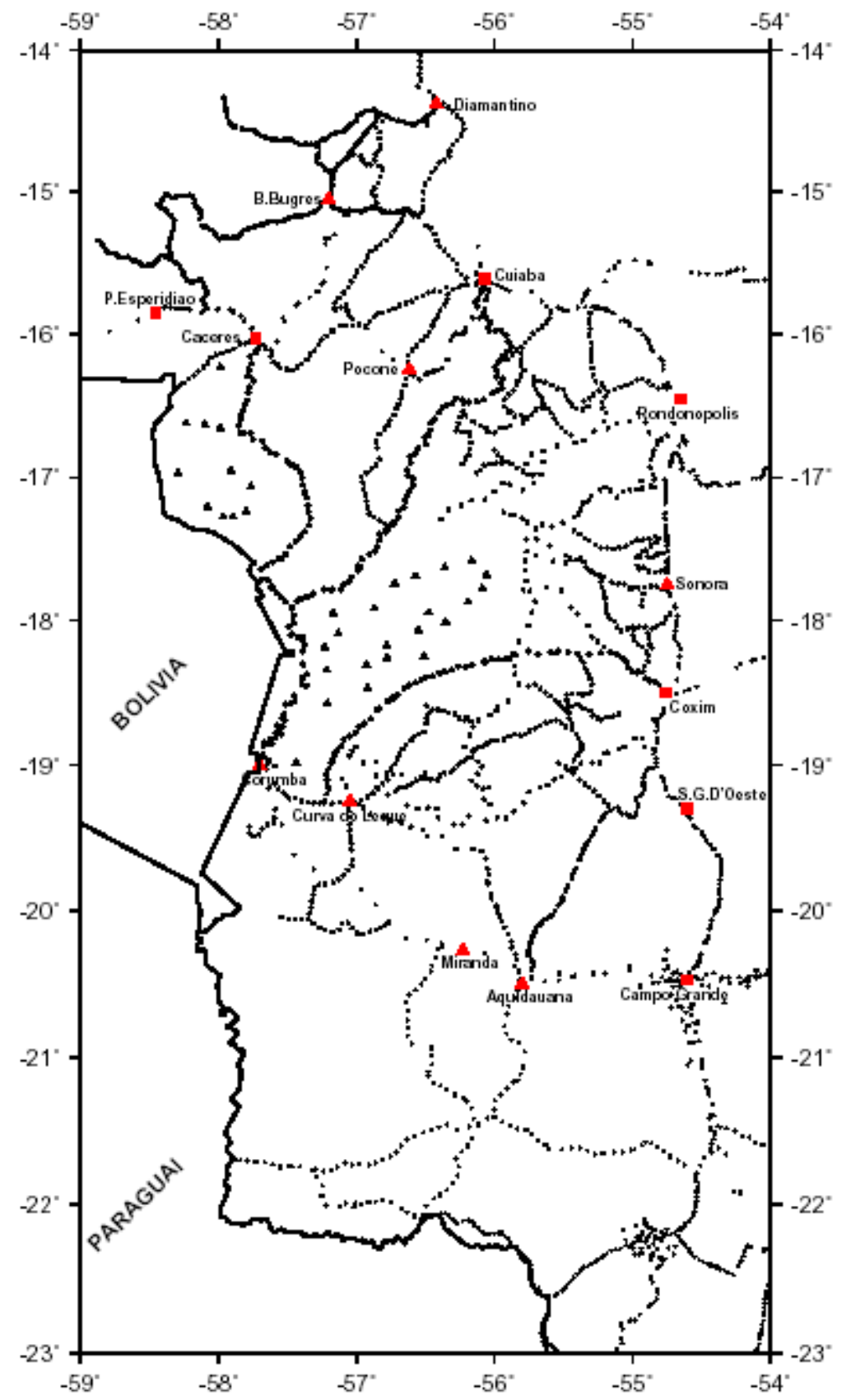

Figure 1 - Distribution of gravity stations in the Pantanal Wetland and surrounding highlands. Full squares are RBG stations, full triangles the second order gravity network, crosses are the stations on bench marks, full circles the stations along the main rivers, full small triangles the stations set up using aircraft, open circles densification gravity survey using barometers and altitude estimated from topographic maps.

Figura 1 - Distribuição das estações gravimétricas do Pantanal Matogrossense e planaltos circunvizinhos. Quadrado cheio são as estações da RBG, os triângulos cheios as estações da rede de segunda ordem, cruzes as estações sobre referências de nível (RN), círculos cheios as estações nas margens dos rios, triângulos pequenos cheios as estações utilizando aeronave, círculos vazios as estações de densificação com altitudes obtidas por barometria ou a partir de cartas topográficas.

Atmosféricas of São Paulo University, the G-613 from the Instituto de Geociências of Brasilia University and the G-881 from Instituto de Ciências Exatas e da Terra of Federal University of Mato Grosso. The measurements were carried out following the international standard recommendation for reference network. Gravity measurements were processed using the software REGRAV (Sá, 1994) which converts gravimeters readings into acceleration (mGal), eliminates instrumental drift and lunar-solar tides using Longman formula and converts station coordinates from Córrego Alegre into the SGB (Sistema Geodésico Brasileiro) and WGS 1984 into SBG. 


\begin{tabular}{|c|c|c|c|}
\hline $\begin{array}{c}\text { Name of } \\
\text { Station }\end{array}$ & $\begin{array}{c}\text { Mean Value } \\
\text { (mGal) }\end{array}$ & $\begin{array}{c}\text { Standard } \\
\text { Deviation (mGal) }\end{array}$ & $\begin{array}{c}\text { Number of } \\
\text { Measurements }\end{array}$ \\
\hline Barra dos Bugres "C" & $978,303.83$ & 0.013 & 5 \\
\hline Barra dos Bugres "B" & $978,298.54$ & 0.022 & 5 \\
\hline Diamantino "C" & $978,252.64$ & 0.046 & 6 \\
\hline Diamantino "B" & $978,250.12$ & 0.046 & 6 \\
\hline Poconé "B" & $978,417.14$ & 0.059 & 6 \\
\hline Poconé "C" & $978,417.60$ & 0.040 & 6 \\
\hline Aquidauana "B" & $978,612.38$ & 0.049 & 4 \\
\hline Aquidauana "C" & $978,612.02$ & 0.046 & 4 \\
\hline Miranda "C" & $978,620.05$ & 0.018 & 4 \\
\hline Miranda "B" & $978,620.00$ & 0.029 & 4 \\
\hline Curva do Leque & $978,589.60$ & 0.034 & 2 \\
\hline Corumbá "C" & $978,561.10$ & 0.016 & 2 \\
\hline Corumbá "B" & $978,561.52$ & 0.044 & 2 \\
\hline Sonora & $978,371.02$ & 0.022 & 4 \\
\hline
\end{tabular}

Table 2 - Average of gravity measurements in the second order gravity network in Mato Grosso and Mato Grosso do Sul states. Values in $\mathrm{mGal}$.

Tabela 2 - Média das medidas de gravidade na rede gravimétrica de segunda ordem implantada nos estados de Mato Grosso e Mato Grosso do Sul. Valores em mGal.

\begin{tabular}{|c|c|c|c|c|}
\hline 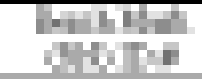 & 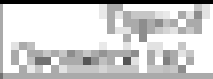 & 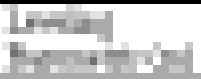 & T.+. & 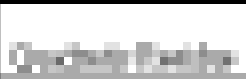 \\
\hline 11: & $11=$ & ans. & Thi & + \\
\hline 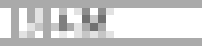 & $111=$ & $1+18$ & $11=$ & $=1$ \\
\hline 11 & .11 & 11 & $=11$ & 14 \\
\hline HE & HEF & $1.7=$ & EEt & |11. \\
\hline Fit & IE & $11=$ & 57 & 11 \\
\hline Hil & 101 & 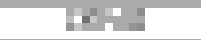 & .11. & $4=$ \\
\hline $\mathbf{H H}$ & 105 & $21+1$ & ARE & 174 \\
\hline HIs & $7+1 !$ & 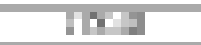 & H & EIt \\
\hline HII & 71tar & 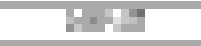 & 21 & 21 \\
\hline 12-1E & HAs & HHIr & 27 & IITH \\
\hline 1... & Hat & 19H & 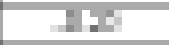 & $=$ \\
\hline H.: & me & HII & E & Mr \\
\hline HH & Hit & 누날 & ER & Els \\
\hline HA & $1+1$ & HII & 11 & 14 \\
\hline E1 & 414 & II & 11 & 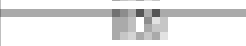 \\
\hline H11 & ins & An & 12 & 114 \\
\hline H1 & $3=1$ & na & 11 & $11+4$ \\
\hline 111 & 1111 & 14 & 71 & Hin \\
\hline min & & & "1-2 & nitin \\
\hline in & & & In & \\
\hline 1121 & & & & 14 \\
\hline Wha & & & 14 & \\
\hline $11=$ & & & Er & \\
\hline
\end{tabular}

Table 3 - Comparison between geometric and barometric leveling in Pantanal Wetland. S.D.R.=Standard Deviation of the Residue; M.Q.R.=Mean Quadratic Residue; Max. R.=Maximum Residue; Min. R.= Minimum Residue.

Tabela 3 - Comparação entre nivelamentos geométrico e barométrico no Pantanal Matogrossense. S.D.R. =Desvio Padrão dos Resíduos; M.Q.R.=Resíduo Quadrático Médio; Max. R.=Resíduo Máximo; Min. R.=Resíduo Mínimo.

The acceleration values in $\mathrm{mGal}$ for this second order gravity network are shown in Table 2 and the stations are shown in Fig. 1 as full triangles.

\section{Densification of Gravity Stations}

The first data to be collected were along the main roads between cities and towns where IBGE had set up the bench marks. They are shown in Fig. 1 as crosses. Almost the totality of horizontal coordinates of the gravity stations were obtained using the Magnavox GPS system with an accuracy of \pm 100 $\mathrm{m}$.

In the Pantanal Wetland plain, where bench marks are very few and for regions located within a distance less than $50 \mathrm{~km}$ from a bench mark, 
barometric leveling was carried out using two batteries of three barometers each. During data collection, bench mark stations were occupied with barometers in order to control the accuracy of the method and the operational condition of the barometers. An example of this checking is shown in Table 3. Stations where the altitude was determined using barometers are shown in Fig. 1 as open circles. Error in the estimated altitude is less than 2 meters.

The second group of gravity data was obtained in regions more than $50 \mathrm{~km}$ far from bench marks. We have used two procedures: first, barometric leveling which gave a mean deviation of 5 meters and second, in regions of very smooth topography (horizontal gradient of 0.20 to 0.40 meters $/ \mathrm{km}$, see Fig. 2) the altitude was estimated from 1:100.000 scale

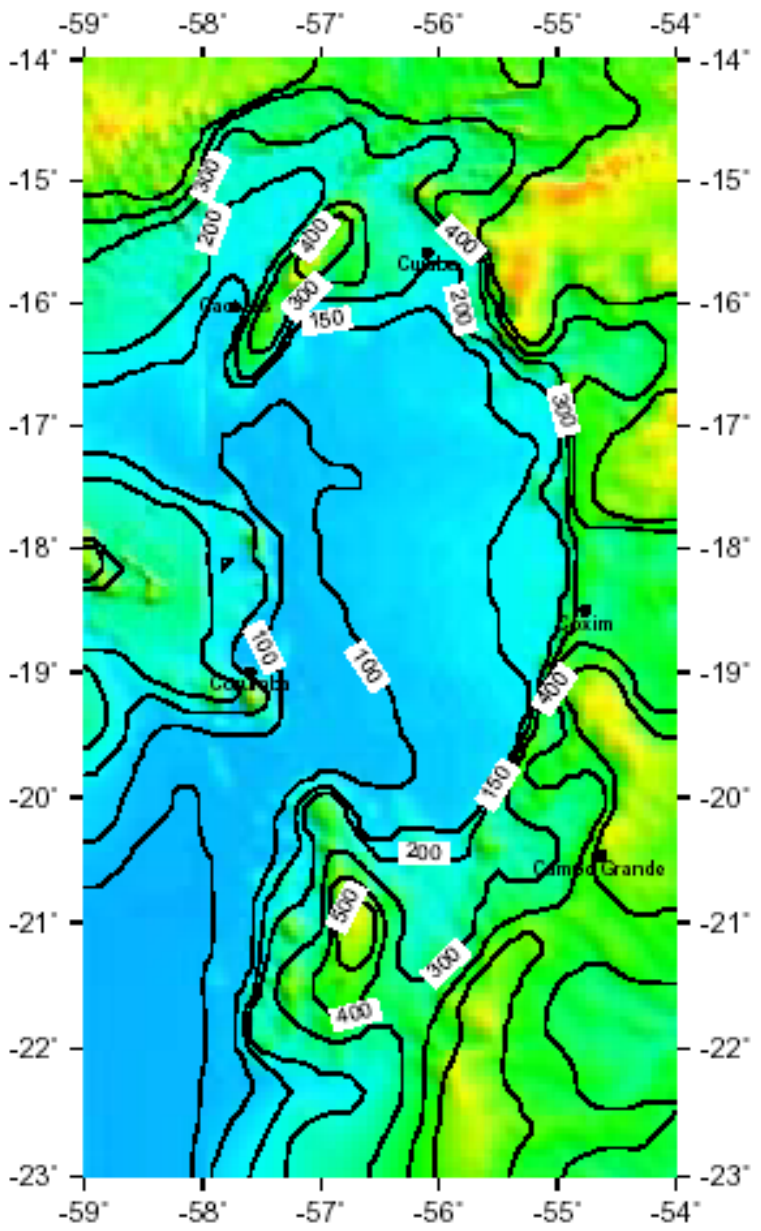

Figure 2 - Shaded relief map of the study area with contours in meters representing the average topography of the gridded $(5 \mathrm{~km}$ x $5 \mathrm{~km}$ ) data. Color version of this map also shown in the front cover of this issue.

Figura 2 - Mapa de relevo sombreado da área de estudo. As curvas de contorno (em metros) representam os valores médios da grade $(5 \mathrm{~km} \times 5 \mathrm{~km})$. A versão colorida deste mapa encontrase na capa deste volume. topographic maps. Stations where altitude was obtained from topographic maps are also shown in Fig. 1 as open circles.

Gravity stations were set up along the margins of three main rivers: Paraguai river (from Cáceres city to Cuiabá river conjunction) with 52 stations collected; Paraguai and Cuiabá rivers from Corumbá to Cuiabá cities where 120 stations were set up with the help of a Brazilian Navy vessel and finally, along the Taquari river from Coxim city to Porto da Manga (near Corumbá city) with 62 stations set up. Altitude for these stations was obtained using the leveling carried out by DNOS (1972) along the Taquari, Cuiabá and Paraguai rivers. The interpolated altitude has an accuracy better than \pm 1 meter. The river stations are shown in Fig. 1 as closed circles.

In the region of almost flat topography within the Taquari river flood plain where access by road or by boat is not possible, an aircraft was used taking advantage of landing facilities in major farms. The first line started and ended in Cáceres city, where 11 stations were set along a circuit of $200 \mathrm{~km}$. A second line started and ended in Corumbá city, where 22 gravity stations were occupied along $500 \mathrm{~km}$ of flown distance. Because of very smooth topographic gradient $(<0.2 \mathrm{~m} / \mathrm{km})$ the altitude for these stations was estimated from the topographic maps and the stations are shown as full triangles in Fig. 1.

\section{GRAVITY MAPS}

Free-air $\left(\Delta g_{a}\right)$ and Bouguer $\left(\Delta g_{b}\right)$ anomalies for each station were calculated using the following expressions:

$$
\begin{aligned}
& \Delta g_{a}=g+0.3086 h-\gamma \\
& \Delta g_{b}=\Delta g_{a}-2 \pi G \rho h
\end{aligned}
$$

where $\mathrm{g}$ is the observed acceleration, $\mathrm{h}$ is the orthometric altitude in meters, $\gamma$ is the 1967 theoretical gravity formula (IAG, 1971) for latitude correction given by

$$
\begin{aligned}
y_{6}= & 978,031.85\left(1+0.005278895 \sin ^{2} \varphi+\right. \\
& \left.+0.000023462 \sin ^{4} \varphi\right) \mathrm{mGal}
\end{aligned}
$$

$\varphi$ is the geographical latitude of the station. 


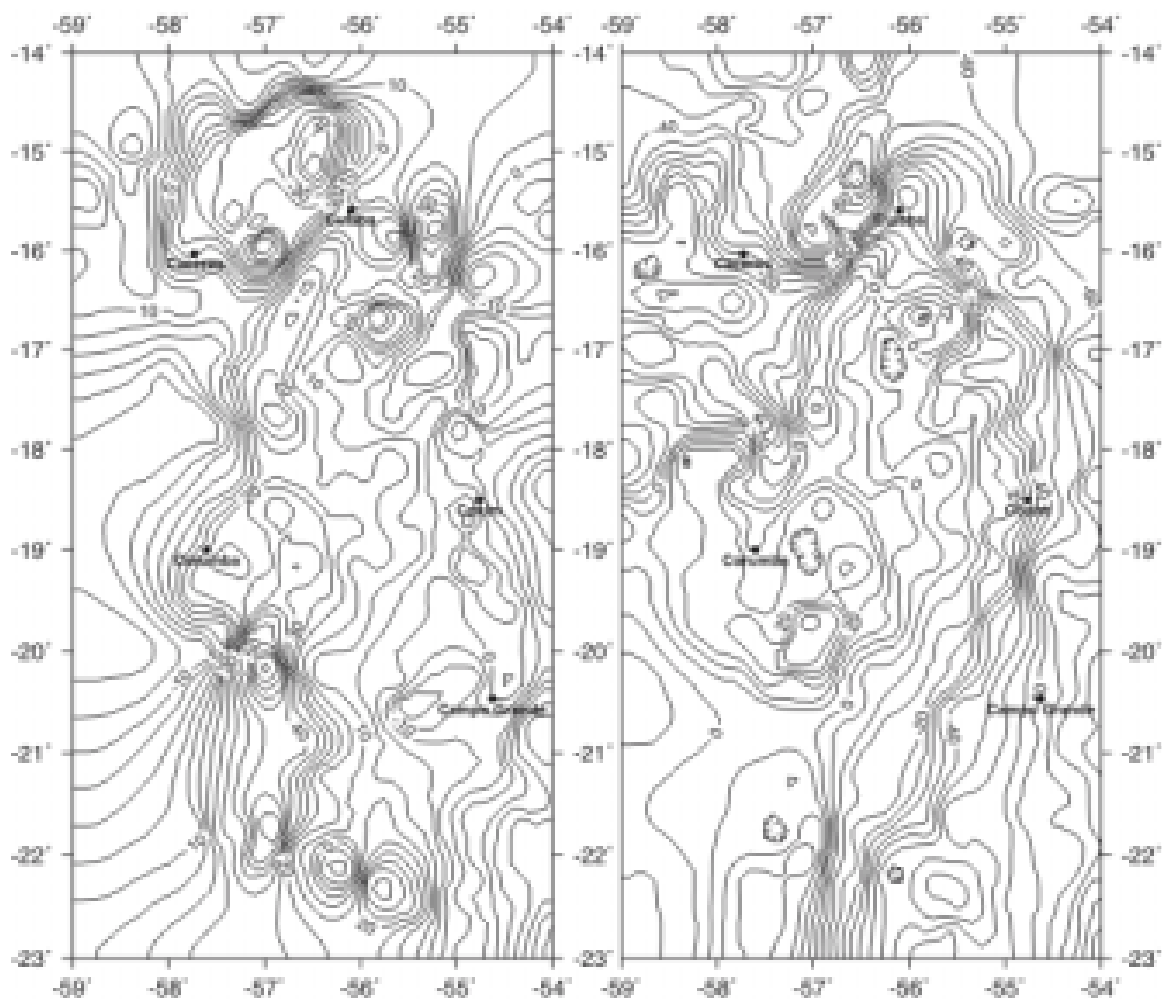

Figure 3 - (a) Free-air anomaly map and (b) Bouguer anomaly map. Contour interval 5 mGal. Color version of Bouguer anomaly map also shown in the front cover of this issue.

Figura 3 - (a) Mapa de anomalias ar-livre e (b) Mapa de anomalias Bouguer. Intervalo de contorno 5 mGal. A versão colorida do mapa de anomalias Bouguer encontra-se na capa deste volume.

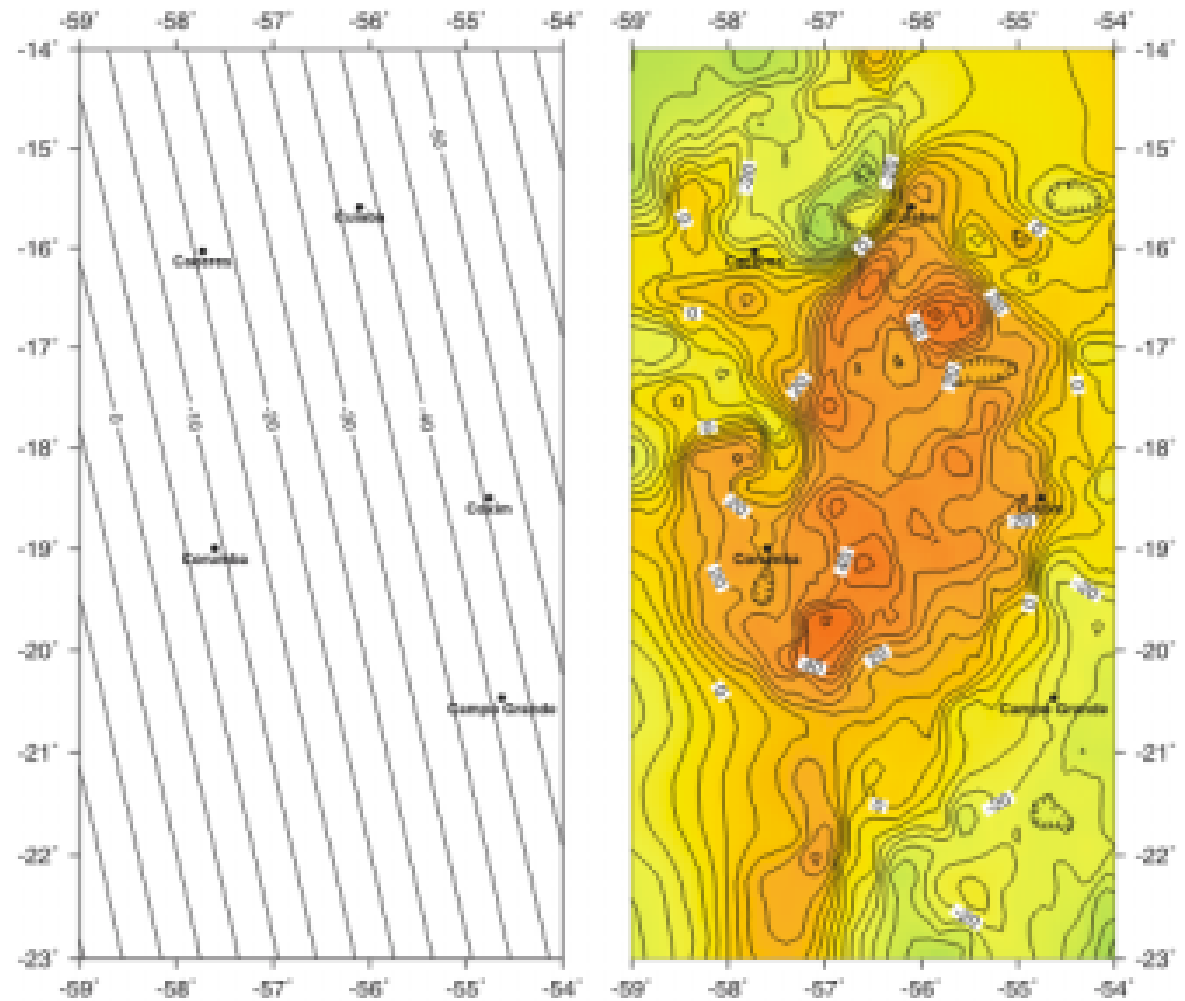

Figure 4 - Regional (left) gravity map after polynomial fitting of first degree to the map shown in Fig. 3(b). Residual gravity map (right) is the difference between map shown in Fig. 3(b) and the regional gravity map.

Figura 4 - Mapa gravimétrico regional (esquerda) após ajuste polinomial de grau um ao mapa mostrado na Fig. 3(b). O mapa de anomalias residuais (direita) é a diferença entre o mapa mostrado na Fig. 3(b) e o mapa gravimétrico regional. 


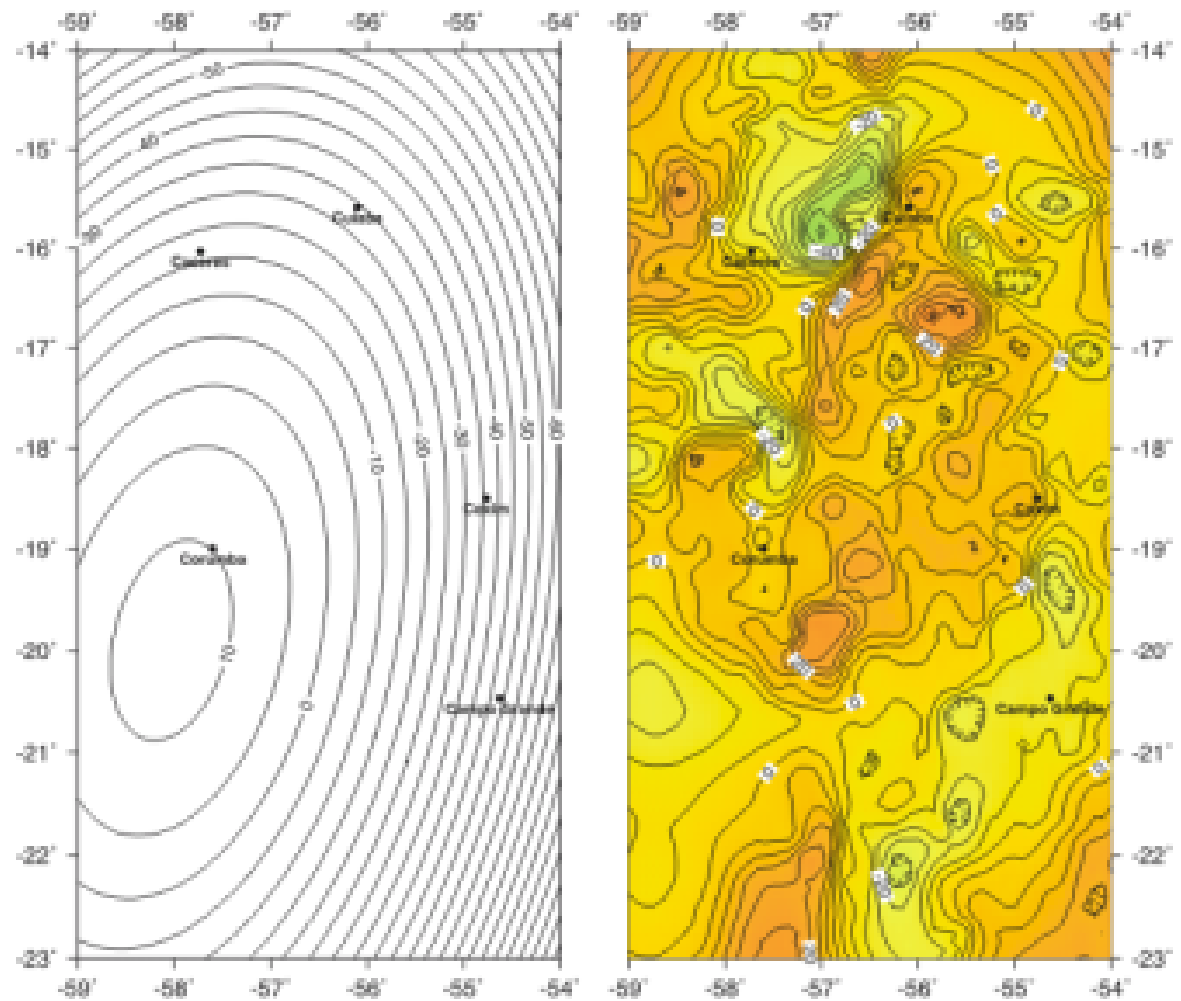

Figure 5 - Regional (left) gravity map after polynomial fitting of second degree to the map shown in Fig. 3(b). Residual gravity map (right) is the difference between map shown in Fig. 3(b) and the regional gravity map.

Figura 5 - Mapa gravimétrico regional (esquerda) após ajuste polinomial de grau dois ao mapa mostrado na Fig. 3(b). O mapa de anomalias residuais (direita) é a diferença entre o mapa mostrado na Fig. 3(b) e o mapa gravimétrico regional.
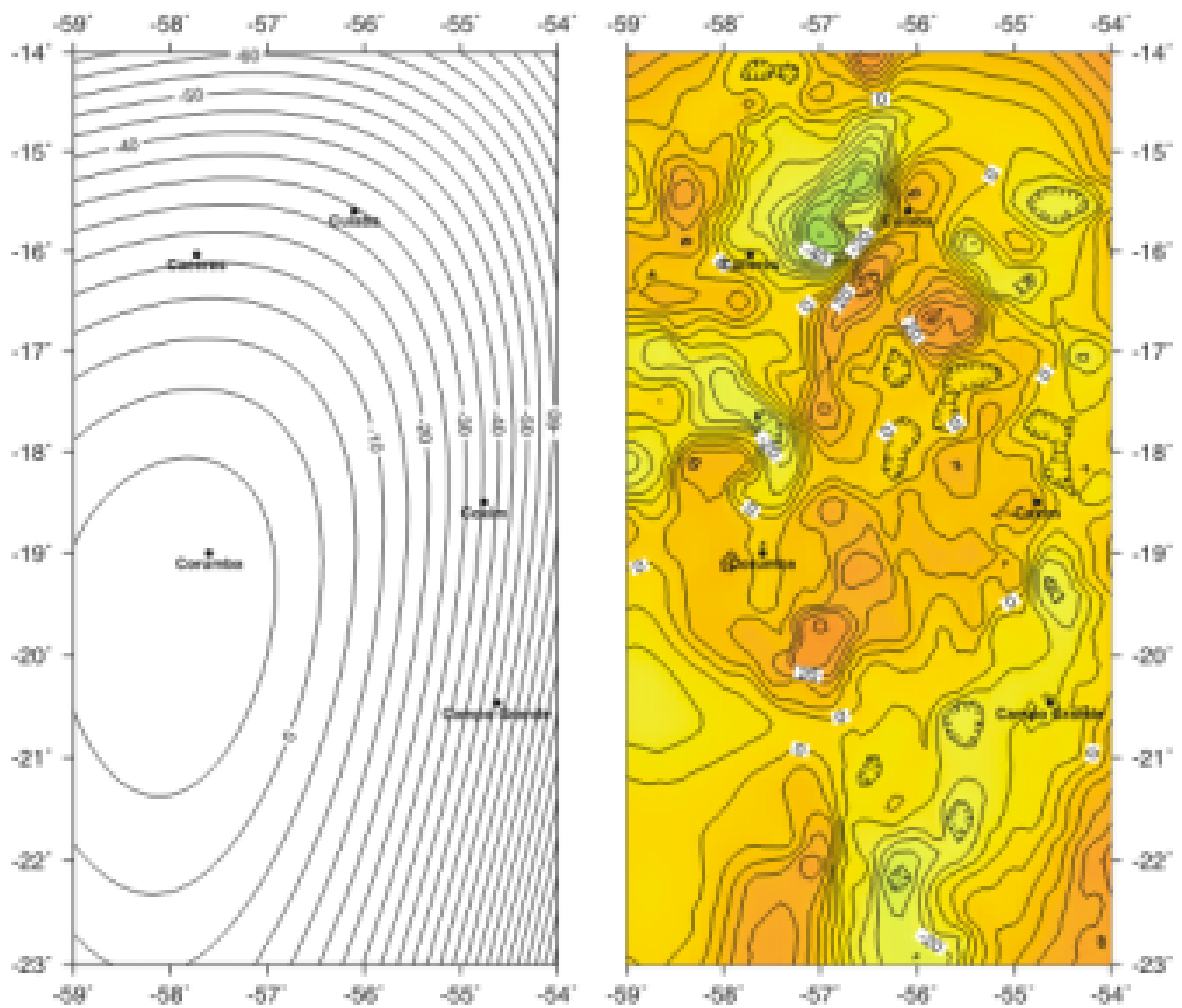

Figure 6 - Regional (left) gravity map after polynomial fitting of third degree to the map shown in Fig. 3(b). Residual gravity map (right) is the difference between map shown in Fig. 3(b) and the regional gravity map.

Figura 6 - Mapa gravimétrico regional (esquerda) após ajuste polinomial de grau três ao mapa mostrado na Fig. 3(b). O mapa de anomalias residuais (direita) é a diferença entre o mapa mostrado na Fig. 3(b) e o mapa gravimétrico regional. 
$\rho$ is the average density of the crust $\left(2,670 \mathrm{~kg} / \mathrm{m}^{3}\right)$ $\mathrm{G}=$ Universal Gravitational Constant $\left(6.673 \times 10^{-11} \mathrm{~N}\right.$ $\mathrm{m}^{2} \mathrm{~kg}^{-2}$ )

\section{Free-Air Anomalies}

Fig. 3a shows the free-air anomaly map in $\mathrm{mGal}$. All maps in this and following sections were generated by initially averaging and resampling the data in 5' $x 5^{\text {' }}$ blocks using $\mathrm{L}_{2}$ norm. Following, a 5'x5' grid was generated using the algorithm proposed by Smith \& Wessel (1990) which use continuous splines with varying tension. This map still shows a strong correlation between gravity anomalies and topographic features of short and intermediate wavelengths.

\section{Bouguer Anomaly and its Regional and Residual Components}

Fig.3b (see color version in the front cover of this volume) shows the simple Bouguer anomaly map in $\mathrm{mGal}$. The main feature is a sequence of positive anomalies aligned along a NE-SW direction, between $-56^{\circ}$ e $-58^{\circ}$. To the east, correlating with higher topography and over the Paraná basin the anomalies are more negatives $(<-50 \mathrm{mGal})$.

In order to highlight short to intermediate wavelength gravity anomalies, associated with sources in the upper crust, results of regional-residual separation procedures using polynomial fitting are presented. They are shown in Fig. 4, 5 and 6. Color versions of all maps can be downloaded from the following internet address: www.iag.usp.br/geofisica/ pantanal.

\section{DISCUSSION AND CONCLUSION}

The uncertainty in the Bouguer anomaly is easily estimated for each station using the expression in (1). The error ranges from $\pm 0.02 \mathrm{mGal}$ for stations located on bench marks to $\pm 0.5 \mathrm{mGal}$ for stations situated more than $50 \mathrm{~km}$ far from a bech mark and which had its altitude determined using barometer or the altitude estimated from 1:100.000 scale topographic maps. The 5'x5' resolution gravity map and the accuracy in anomaly determination for most of the
Pantanal Wetland provide a detailed mapping of subsurface structures in regional tectonic studies and a precision better than $\pm 0.5 \mathrm{~m}$ in geoid determination. Large areas between gravity lines, especially in the southern part of the map $\left(-19^{\circ}\right.$ to $\left.-23^{\circ}\right)$ outside the Pantanal Wetland should be densified using secondary roads in order to improve the gravity map resolution in this region, making full use of the higher accuracy of Bouguer anomaly determination on bench marks.

\section{ACKNOWLEDGEMENTS}

This project of data collection was supported by PADCT/FINEP and FAPESP. The senior author had UFMT PICDT-Capes Doctorate Scholarship during the period of the project. We thank Nelsi C. de Sá and Eder C. Molina for their assistance in data reduction and processing, Odilon F.Miranda Filho and Alexandrino do Nascimento for keeping the enthusiasm constant during field data acquisition. All maps were produced using GMT-System free-software by P.Wessel and W.H.F. Smith.

\section{REFERENCES}

DNOS (Departamento Nacional DE Obras E Saneamento), 1972. Estudos hidrológicos da Bacia do Alto Paraguai. Ministério do Interior, Rio de Janeiro. 4 volumes.

I.A.G. (International Association of Geodesy), 1971. Geodetic Reference System 1967. Pub. Spec. No. 3 du Bulletin Géodésique, 115 pp.

Molina, E.C. \& Ussami, N., 1999. The geoid in southern Brazil and adjacent regions: new constraints on density distribution and thermal state of the lithosphere. J. of Geodynamics, 28, 357-374.

Molina, E.C., Ussami, N. \& Marangoni, Y.R., 2000. Digital (5' x 5') Gravity Maps of the São Francisco Cráton and surrounding fold belts, margins and oceanic basins. CD-ROM with gridded data, explanatory texts and maps. ISBN 85-85047-09-7, second edition. IAG-USP, São Paulo.

Morelli, C., Gantor, C., Honkasalo, T., McConnell, R.K., Tanner, J.G., Szabo, B., Votila, V. \& Whalen, C.T., 1971. The International Gravity Standardisation Net. Pub. Spec. no. 4 du Bulletin Géodésique. 
ON (Observatório Nacional), 1987. Rede Gravimétrica Fundamental Brasileira, Conselho Nacional de Pesquisas, 2 volumes.

Sá, N.C. de; Ussami, N. \& Molina, 1993. Gravity Map of Brazil I: Representation of free-air and Bouguer anomalies, J. Geophys. Res., 98, 2,1872,198.

Sá, N.C. de, 1994. Redução de observações gravimétricas: teoria e prática. Instituto Astronômico e Geofísico da USP, São Paulo, 70 pp.
Shiraiwa, S., 1994. Flexura da litosfera continental sob os Andes Centrais e a origem da Bacia do Pantanal. Tese de Doutoramento, Universidade de São Paulo, São Paulo, 110 pp.

Smith, W.H.F. \& Wessel, P., 1990. Gridding with continuous curvature splines in tension. Geophysics, 3, 293-305.

Ussami, N., Shiraiwa, S. \& Dominguez, J.M.L., 1999. Basement reactivation in a sub-Andean foreland flexural bulge: The Pantanal Wetland, SW Brazil. Tectonics, 18(1), 25-39.

\section{THE 36-51 $1^{\text {th }}$ MOST VISITED RBG ARTICLES AT WWW.SCIELO.BR/RBG}

(from February 26, 1998 to July 14, 2003)

\begin{tabular}{|c|c|}
\hline $\begin{array}{c}\begin{array}{c}\text { number } \\
\text { of } \\
\text { requests }\end{array} \\
\end{array}$ & articles \\
\hline 78 & $\begin{array}{l}\text { ASSUMPCAO, M., BARBOSA, J. R., BERROCAL, J. et al. Seismicity patterns and focal mechanisms in } \\
\text { southe astern Brazil. Rev. Bras. Geof., July } 1997 \text {, vol.15, no. } 2, \text { p.119-132. }\end{array}$ \\
\hline 77 & $\begin{array}{l}\text { MACHADO, Sérgio Augusto Morais and PEN HA, Ulisses Cyrino. Structure of the Rio Mata Cavalo volcano- } \\
\text { sedime ntary sequence (Morro do Pilar, MG, Brazil) based on qualitative analysis of geop hysical data. Rev. Bras. } \\
\text { Geof., July 1997, vol.15, no.2, p.145-152. }\end{array}$ \\
\hline 73 & $\begin{array}{l}\text { FIGUEIREDO JR., A lberto G. and BREHME, Isa. Geological sampling in mineral exploration. Rev. Bras. Geof., } \\
2000 \text {, vol.18, no.3, p.260-280. }\end{array}$ \\
\hline 71 & $\begin{array}{l}\text { LEITAO, Mário de Miranda Vilas Boas Ramos. Radiation balance in three amazonian ecosystems: "campina", } \\
\text { "campinarana" and "mata densa". Rev. Bras. Geof., Mar. 1999, vol.17, no.1, p.84-85. }\end{array}$ \\
\hline 71 & $\begin{array}{l}\text { RIGOZO, N. R. and NORDEMANN, D. J. R. Record of solar activity in tree growth-rings from São Francisco de } \\
\text { Paula - RS (Brazil). Rev. Bras. Geof., Mar. 2000, vol.18, no.1, p.91-97. }\end{array}$ \\
\hline 70 & $\begin{array}{l}\text { CARMO, Alexandre Me lo Casseb do. Study of atmospheric thermodynamic structure over Amazo nia. Rev. Bras. } \\
\text { Geof., Mar. } 1999 \text {, vol.17, no.1, p.90-90. }\end{array}$ \\
\hline 70 & $\begin{array}{l}\text { QUARESMA, V. S., DIAS, G. T. M. and BAPTISTA NETO, J. A. Characterization of side-scan sonar and high } \\
\text { resolution seismic (35-7.0 kHZ) reflection patterns along the Southern margin of the Guanabara Bay - RJ. Rev. } \\
\text { Bras. Geof., May/Aug. } 2000 \text {, vol.18, no.2, p.201-214. }\end{array}$ \\
\hline 68 & SILVA, Cleverson G. Marine placers. Rev. Bras. Geof, 2000 , vol.18, no.3, p. $327-336$. \\
\hline 65 & $\begin{array}{l}\text { VEISSID, N. and PEREIRA, E. B. Assessment of the Plane tary Albe do by using data from the Solar Cell } \\
\text { Experiment of the Braxilian SCD2 satellite. Rev. Bras. Geof., Mar. } 2000 \text {, vol.18, no.1, p. } 25-38 \text {. }\end{array}$ \\
\hline 62 & $\begin{array}{l}\text { BOURCHTEIN, A. Comparative study of two economic methods applied to a numerical sche me of we ather } \\
\text { prediction. Rev. Bras. Geof., Mar. } 1998 \text {, vol. } 16 \text {, no. } 1, \text { p. } 27-36 \text {. }\end{array}$ \\
\hline 61 & $\begin{array}{l}\text { SANTOS, N. P. and ESCOBAR, I. P. Gravime tric geoid determination in the municipality of Rio de Janeiro and } \\
\text { nearby region. Rev. Bras. Geof., Mar. } 2000 \text {, vol. } 18 \text {, no. } 1, \text { p. } 50-62 \text {. }\end{array}$ \\
\hline 60 & $\begin{array}{l}\text { LEITE, L. W. B. and ROCHA, M. P. C. da. Deconvolution of non-stationary seismic process. Rev. Bras. Geof., Mar. } \\
2000 \text {, vol.18, no.1, p. } 75-89 \text {. }\end{array}$ \\
\hline 60 & $\begin{array}{l}\text { LOPES, Eliezer P. and LOPES, Elizeu P. Assessing the influe nce of the ground-air interface on polarime tric } \\
\text { borehole-radar data. Rev. Bras. Geof., May/Aug. } 2000 \text {, vol. } 18 \text {, no. } 2, \text { p. } 117-128 \text {. }\end{array}$ \\
\hline 59 & $\begin{array}{l}\text { SOUZA, J. M. de. Mar territorial, zona econômica exclusiva ou plataforma continental. Rev. Bras. Geof., Mar. } 1999 \text {, } \\
\text { vol. } 17 \text {, no. } 1, \text { p. } 79-82 \text {. }\end{array}$ \\
\hline 58 & $\begin{array}{l}\text { VELHO, H. F. de C. and RAMOS, F. M. Numerical inversion of two-dime nsional ge oelectric conduc tivity } \\
\text { distributions from magne to telluric data. Rev. Bras. Geof., July } 1997 \text {, vol.15, no.2, p.133-144. }\end{array}$ \\
\hline 58 & $\begin{array}{l}\text { HELBIG, Klaus. Layer-induce d elastic anisotropy - part } 1 \text { : forward relations be tween constituent parameters and } \\
\text { compound medium parame ters. Rev. Bras. Geof., Julv/Nov. 1998, vol.16, no.2-3,p.103-114. }\end{array}$ \\
\hline
\end{tabular}


CI TING I O URNAL LIS TING FOR REV. BRAS . GEO F. Included In the SCIELO Data Base - Year Base 2000

\begin{tabular}{|c|c|c|c|c|c|c|c|c|c|c|c|c|c|c|}
\hline \multirow{2}{*}{ cited journals } & \multicolumn{14}{|c|}{ Humber of citations from articles published in 2000} \\
\hline & total & 2000 & 1999 & 1998 & & 1997 & 1996 & & 1995 & $\longdiv { 1 9 9 4 }$ & 1993 & 1992 & $\longdiv { 1 9 9 1 }$ & K1991 \\
\hline total citations: & 83 & & $\overline{4} \mathbf{3}$ & & $5 \Gamma$ & & $\overline{5}$ & 5 & 4 & 18 & 3 & $\overline { 3 } \longdiv { 4 }$ & 1 & 31 \\
\hline $\begin{array}{l}\text { BOLETIM DE GEOCIENCIAS DA } \\
\text { PETROBRAS }\end{array}$ & 17 & & & & - & & - & - & 1 & 14 & - & - & & \\
\hline NATURE & 9 & & -1 & & 1 & & - & - & - & - & - & - & $=$ & 8 \\
\hline SCIENCE & 7 & & -1 & & -1 & & 1 & 1) & - & - & 1 & - & - & 4 \\
\hline GEOLOGY & 5 & & - & & - & & 1 & - & - & $\overline{2}$ & -1 & - & 1 & \\
\hline TECTONOPHYSICS & 5 & & -1 & & - & & - & $\overline{2}$ & $=$ & - & $\overline{1}$ & $\overline{2}$ & 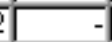 & \\
\hline REV. BRAS. GEOF. & 4 & 1 & 1 & & 1 & & - & $\overline{1}$ & - & $\overline{1}$ & - & - & - & $=$ \\
\hline REV. BRAS. GEOCIENC. & 3 & & -1 & & 1) & & - & - & - & - & - & - & $=$ & \\
\hline $\begin{array}{l}\text { ANNABLS OF THE NEW YORK } \\
\text { ACADEMY OF SCIENCES }\end{array}$ & 2 & & 2 & & - & & & & & & & & & \\
\hline $\begin{array}{l}\text { EEE TRANSACTIONSON } \\
\text { ANTENNASAND PROPAGATION }\end{array}$ & 2 & & & & & & & & 1 & 1 & & - & & \\
\hline MARINE BIOLOGY & 2 & & -1 & & - & & - & - & 1 & - & -1 & 1 & & \\
\hline $\begin{array}{l}\text { MARINE ECOLOGY PROGRESS } \\
\text { SERIES }\end{array}$ & 2 & & 1 & & & & & & - & - & & - & & \\
\hline PROCEEDINGS OF THE IEEE & 2 & & & & - & & - & & $=$ & - & - & $=$ & & \\
\hline RADIOSCIENCE & $\overline{2}$ & & - & & - & & - & $=$ & $=$ & - & - & $=$ & $=$ & \\
\hline ADVANCES IN MARINE BIOLOGY & 1 & & -1 & & 1) & & - & - & - & - & - & $=$ & $=$ & \\
\hline AN. ACAD. BRAS. CIENC. & 1 & & -1 & & -1 & & $=$ & - & - & - & 1 & - & & \\
\hline ANNUAAL REVIEW OF ENERGY & 1 & & & & -1 & & & & - & - & & $=$ & & \\
\hline ATMOSPHERIC ENVIRONMENT & 1 & & & & -1 & & $=$ & $\overline{1}$ & - & - & - & $=$ & & $=$ \\
\hline BIOMETRIKA & 1 & & -1 & & -1 & & - & & - & - & - & - & $=$ & 1 \\
\hline $\begin{array}{l}\text { CANADIAN JOURNAL OF } \\
\text { ZOOLOGY }\end{array}$ & 1 & & & & & & & & & & & $\overline{1}$ & & \\
\hline CIENC. HOJE & 1 & & - & & - & & 1 & & - & - & & - & $=$ & \\
\hline $\begin{array}{l}\text { ENVIRONMENTAL TOXICOLOGY } \\
\text { AND CHEMISTRY }\end{array}$ & 1 & & & & & & 1 & & & & & & & \\
\hline ES & 1 & & & & & & - & & & - & & - & - & \\
\hline $\begin{array}{l}\text { EEE TRANSACTIONS ON } \\
\text { NSTRUMENTATION AND } \\
\text { MEASUREME }\end{array}$ & 1 & & & & & 1 & 1 & & & & & & & \\
\hline J.GEOL. & 1 & & - & & - & & - & & - & - & & - & & \\
\hline $\begin{array}{l}\text { JOURNAL OF PLANKTON } \\
\text { RESEARCH }\end{array}$ & 1 & & & & - & & & & 1 & - & & & & \\
\hline N.SCl. & 1 & & -1 & & - & & - & & - & - & & & & \\
\hline NATUR UND MUSEUM & $\overline{1}$ & & -1 & & -1 & & - & & - & - & -1 & - & - & 1 \\
\hline $\begin{array}{l}\text { OCEANOGRAPHY AND MARINE } \\
\text { GIOLOGY; ANN ANNNUAL REVIEW }\end{array}$ & 1 & & & & 1 & & & & & - & & - & & \\
\hline $\begin{array}{l}\text { PHILOSOPHICAL } \\
\text { TRANSACTIONS OF THE ROYAL } \\
\text { SOCIETY OF }\end{array}$ & 1 & & 1 & & & & & & & & & & & \\
\hline SCIENTIFIC AMERICAN & $\overline{1}$ & & & & & & & & & - & & - & & \\
\hline $\begin{array}{l}\text { TRANSACTIONS OF THE ROYAL } \\
\text { SOCIETY OF CANADA }\end{array}$ & 1 & & & & & & & & & - & & & & \\
\hline $\begin{array}{l}\text { TRENDS IN ECOLOGY AND } \\
\text { EVOLUTION }\end{array}$ & 1 & 1 & 1 & & & & & & & & & & & \\
\hline TECTONICS & 1 & & - & & -1 & & $=$ & & & - & - & - & & \\
\hline MATER RESOURCES RESEARCH & 1 & & - & & - & & - & & & - & & - & & \\
\hline
\end{tabular}

